\title{
MODERN MODEL OF INTEGRAL RISK EVALUATION OF DISEASES WITH TEMPORARY DISABILITY IN THE WORKERS OF MODERN MINING AND SMELIING INDUSTRY OF UKRAINE
}

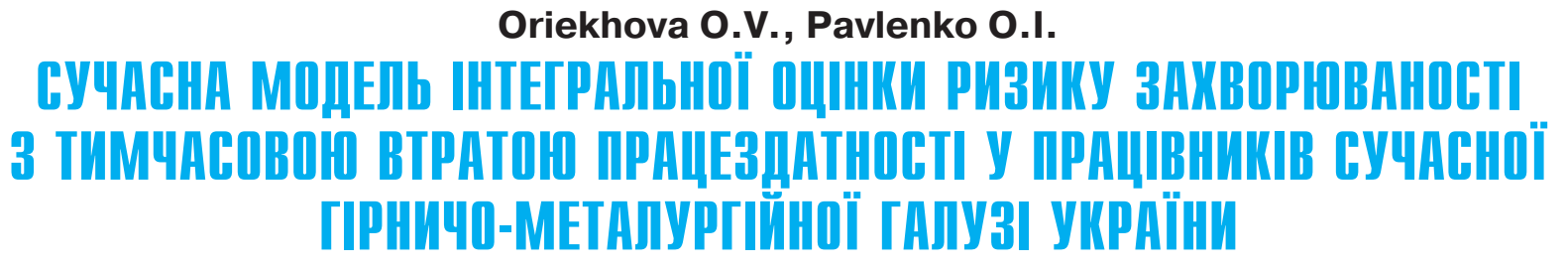

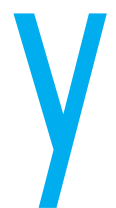

OPEXOBA O.B., ПАВЛЕНКО О.І.

ДУ «Український

науково-дослідний інститут

промислової медицини», м. Кривий Ріг, Україна

Ключові слова: професійний ризик, захворюваність з тимчасовою втратою працездатності, інтегральна оцінка, гірничометалургійна галузь. сучасному світі зростає значущість здоров'я як незаперечної цінності та фундаментального невід'ємного права людини. Громадське здоров'я $€$ важливим ресурсом і джерелом економічної і соціальної стабільності. Підставою для визначення основних завдань державної політики у сфері охорони професійного здоров'я та напрямків їх реалізації стає загальний аналіз стану здоров'я та умов праці в Україні [1-3].

Здоров'я працівників $€$ не тільки біологічною, а й соціальною категорією, що формується під впливом комплексу факторів, серед яких умови праці, економічні умови, спосіб та якість життя $є$ провідними і визначають рівень здоров'я популяції та трудовий потенціал будь-якої країни. Саме це і відображає безпосередній зв'язок медичних і економічних аспектів охорони здоров'я через вплив на стан трудових ресурсів. Людський капітал як економічна категорія, яка сприяє зростанню добробуту суспільства, його економічної незалежності, обороноздатності, культурного розвитку, посідає провідне місце у системі виробничо-трудових відносин. Відтворення продуктивних сил, покращання здоров'я працівників, збереження генофонду нації $€$ важливим напрямком державної політики України, визначеним Конституцією України [4].
СОВРЕМЕННАЯ МОДЕЛЬ ИНТЕГРАЛЬНОЙ ОЦЕНКИ РИСКА ЗАБОЛЕВАНИЙ С ВРЕМЕННОЙ УТРАТОЙ ТРУДОСПОСОБНОСТИ У РАБОТНИКОВ СОВРЕМЕННОЙ ГОРНО-МЕТАЛЛУРГИЧЕСКОЙ ОТРАСЛИ УКРАИНЫ Орехова О.В., Павленко А.И.

ГУ «Украинский научно-исследовательский институт промышленной медицины", г. Кривой Рог, Украина

Цель исследования: гармонизация метода анализа и оценки заболеваемости, связанной с условиями труда, с международными стандартами. Материалы и методы. В исследованиях использовались гигиенические, эпидемиологические и математико-статистические методы.

Основную группу представляли 19033 рабочих 8-ми ведущих горнометаллургических предприятий. Контрольная группа - 6270 человек, которые в процессе работы не подвержены вредным производственным факторам.

Исследование случаев временной нетрудоспособности проводилось на основе анализа больничных листов и Отчета о причинах временной нетрудоспособности (форма TN-23) за 5 лет (2010-2014).

Результаты. Предложен подход к оценке риска заболеваемости с временной утратой трудоспособности (ВУТ), который, в отличие от существующего, позволяет не только оценить уровень заболеваемости, но и выявить причины ее изменения и дать количественную оценку влияющим на нее факторам (вредное производство, медицинское обслуживание, качество профессионального отбора и т.д.). Количественная корре- ляция между этими факторами является прочным основанием для разработки профилактических мероприятий, позволяющих снизить уровень профессиональной патологии на 7-15\% и избежать от 7 до 40 лет трудовых потерь для государства и предприятий.

Установлено, что риск развития общих заболеваний выше, чем у контрольной группы: при подземной добыче железной руды $(R R=0,127)$, при открытой добыче железной руды $(R R=0,173)$ и в металлургическом производстве $(R R=0,161)$, а соотношение шансов профессионального заболевания (OR) составляет 0,0516, 0,041 и 0,0061 соответственно. Работники основных профессий имеют высокий относительный риск $(R R)$ развития заболеваемости с ВУТ - от 9,5 до 52,1 .

Этиологическая часть профессиональных факторов в развитии заболеваний с ВУТ составляет 94, 7-98, 1\%, что свидетельствует о высокой степени связи с условиями труда и очень высоком профессиональном факторе риска развития риска заболеваемости с ВУТ на рабочем месте. Предлагаемые показатели заболеваемости, рассчитанные на основе анализа частоты временной нетрудоспособности, необходимы для оценки риска развития профессиональной и профессионально обусловленной патологии, в то время как интегральные показатели, учитывающие частоту заболеваний и степень тяжести последствий, имеют решающее значение.

Ключевые слова: профессиональный риск, заболеваемость с временной утратой трудоспособности, интегральная оценка, горно-металлургическая отрасль.

() Орєхова О.В., Павленко О.І. СТАТТЯ, 2019. 
Стан здоров'я працездатного населення формується як за рахунок характеру та умов праці, так і за рахунок інших факторів: генетичних, екологічних, способу життя, доступності медичної допомоги, віко-статевих характеристик населення, співробітництва працівників, роботодавців, закладів охорони здоров'я тощо $[1,5,6]$.

За даними ВООЗ, близько 25\% хвороб можуть бути пов'язаними з працею. У комплексі факторів, що впливають на здоров'я, важливу роль відіграють професійні ризики: від $20 \%$ до 40\% працевтрат обумовлені захворюваннями, прямо або опосередковано пов'язаними 3 несприятливими умовами праці [7-9].

Таким чином, в умовах реформування медичної галузі 3 урахуванням принципів доказової медицини проблема стану професійної захворюваності в Україні $€$ актуальною та потребує наукової дискусії і пошуку нових механізмів впливу на фактори та умови виникнення професійних захворювань [2].

Нині проблема збереження трудового довголіття є актуальною та визначається демографічними факторами, передусім чисельністю населення віком 20-65 років (саме ці вікові групи визначають економічно активний вік).

Разом з тим, для адекватного вирішення питань управління ризиком погіршення здоров'я працівників та для розробки оздоровчих заходів, спрямованих на зниження захворюваності, необхідно визначити причини, що призводять до зростання захворюваності, та встановити причино-наслідковий зв'язок насамперед з виробничопрофесійними факторами

Мета дослідження полягає у гармонізації методики аналізу та оцінки захворюваності, що пов'язана з умовами праці, 3 міжнародними стандартами.

Матеріали та методи дослідження. Оцінка професійного ризику шляхом аналізу захворюваності 3 тимчасовою втратою працездатності (ЗТВП) виконувалася методом аналітичного ретроспективного когортного повздовжнього непаралельного дослідження. Поглиблене вивчення ЗТВП проводилося ретроспективно шляхом суцільного способу дослідження, яке допускає облік та розробку усіх випадків непра- цездатності у зв'язку з захворюваннями та травмами. Вид спостереження - поточний, облік ЗТВП проводився безперервно.

При аналізі захворюваності враховувались усі випадки непрацездатності, що зареєстровані протягом звітного періоду. Одиницею спостереження був випадок непрацездатності через хворобу. Для більш поглибленого аналізу одиницею спостереження може виступати хворий працівник.

Первинними документами, що засвідчують тимчасову непрацездатність через хворобу, $\epsilon$ «Лікарняний листок», затверджений Наказом Міністерства охорони здоров'я України, Міністерства праці та соціальної політики України, Фонду соціального страхування з тимчасової втрати працездатності, Фонду соціального страхування від нещасних випадків на виробництві та професійних захворювань України від 03.11 .2004 р. № 532/274/136ос/1406, який зберігається у бухгалтерії промислового підприємства.

«Листок непрацездатності» $€$ юридичним документом, фінансовим (є підставою для матеріальних виплат) та статистичним.

На підставі листків непрацездатності підприємство складає звіт про причини тимчасової непрацездатності за рік, півріччя, квартал.

Спочатку рахують загальну кількість листків непрацездатності, а потім розподіляють їх за групами залежно від мети дослідження.

При аналізі ЗТВП за стандартною методикою Догле Н.В., Юркевич А.Я. [10] до основних показників відносять дні тимчасової непрацездатності через хворобу, випадки тимчасової непрацездатності через хворобу, середню тривалість випадку тимчасової непрацездатності через хворобу, показники структури (питома вага) випадків та днів непрацездатності окремих форм захворюваності, що розраховуються на підставі листків непрацездатності.

Основна група дослідження була представлена 19033 працівниками 8-ми провідних підприємств гірничо-металургійного виробництва (Північний гірничо-збагачувальний комбінат, Центральний гірничо-збагачувальний комбінат, Інгу- лецький гірничо-збагачувальний комбінат, Криворізький залізорудний комбінат, Евраз Суха Балка, «АрселорМіттал» Кривий Ріг, Дніпропетровський металургійний завод імен Петровського, «Запоріжсталь», металургійний завод «Дніпроспецсталь») та у лабораторіях Українського науково-дослідного інституту промислової медицини.

Контрольна група - 6270 працівників, які у процесі своєї трудової діяльності не зазнають впливу шкідливих виробничих факторів.

Вивчення захворюваності з тимчасовою втратою працездатності (ЗТВП) було проведено на підставі аналізів листків непрацездатності та звіту про причини тимчасової непрацездатності (форма ТН 23) за 5 років (2010-2014).

Обробку матеріалу проводили з застосуванням стандартного пакета програм Microsoft Office Excel. Отримані дані мали нормальний закон розподілу ймовірностей і для їх аналізу використовувалися переважно параметричні критерії Ст'юдента і Фішера. Кількість спостережень була достатньою для отримання незміщених оцінок перших двох моментів: середньої арифметичної (М) та середньоквадратичного відхилення $(\delta)$. Для порівняння середніх величин кількісних показників за нормального розподілу ознаки використовували t-критерій Ст'юдента. Достовірним вважали рівень значущості $\mathrm{p}<0,05$ з надійністю 95\%.

Результати та обговорення. Обов'язковою умовою вивчення та аналізу впливу умов праці на захворюваність є співставлення і порівняння показників захворюваності основної та контрольної груп, які формуються з декількох виробничопрофесійних груп, що піддавалися впливу того самого фактора різної інтенсивності, або професійних груп, які мають різний стаж роботи у конкретних виробничо-професійних умовах, що відображає тривалість впливу цих умов і факторів, роль яких вивчається.

Формуючи групи порівняння для отримання достовірних результатів, необхідно забезпечити однорідність груп дослідження за статтю, віком подібними за виробничо-професійними, соціально-побутовими, кліматичними умовами, 
харчуванням, комунальним обслуговуванням, якістю надання медичної допомоги працівникам тощо.

у разі неможливості формування однорідних груп дослідження та істотних відмінностей розподілу за віком та стажем необхідно проводити додаткову стандартизацію за даними ознаками, якою передбачається усунення зазначених ознак для встановлення впливу виробничо-професійних умов.

Вибір і формування груп працівників, захворюваність яких вивчається та порівнюється, повинні забезпечити максимальну схожість їх і відмінність за комплексом тих факторів, які необхідно проаналізувати та оцінити.

Осіб, які у процесі трудового стажу зазнавали впливу шкідливих виробничих факторів різного ступеня шкідливості, доцільно виключити із дослідження або виділити їх у самостійну групу.

Із контрольної групи виключають осіб, для яких встановлено зв'язок захворювання з умовами праці та яких переведено на роботу без впливу шкідливого виробничого фактора.

Нами запропоновано підхід до оцінки ризику захворюваності з тимчасовою втратою працездатності, який на відміну від існуючого дозволяє не тільки оцінити рівень ЗТВП, але й виявити причини його зміни та дати кількісну оцінку факторів, що на нього впливають: виробничі шкідливі фактори, медичне забезпечення, якість професій-

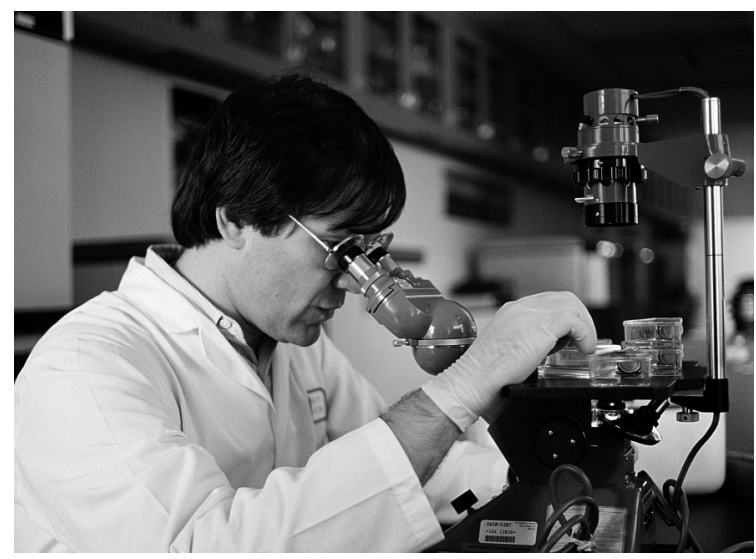

ДОВКІЛЛЯ: НОВІ МЕТОДИ ОЦІНКИ 틀

ного добору тощо. Кількісне співвідношення між цими факторами являє собою тверде підґрунтя для розробки профілактичних заходів, що дає змогу знизити рівень професійної патології на 7-15\% та уникнути від 7 до 40 років трудових втрат для держави та підприємства.

Запропоновані показники захворюваності, які розраховуються на підставі аналізу захворюваності 3 тимчасовою втратою працездатності, $€$ необхідними для оцінки ризику розвитку професійної та професійно зумовленої патології, при цьому інтегральні показники, що враховують частоту захворювань та важкість наслідків, Є визначальними.

Крім того, це дає змогу безпосередньо оцінити умови праці шляхом аналізу захворюваності з тимчасовою втратою працездатності контингенту працівників, які досліджуються.

Зниження захворюваності 3 тимчасовою втратою працездатності набуває не лише соці- ального, а й економічного значення.

Аналізом показників захворюваності $з$ тимчасовою втратою працездатності встановлено, що найбільше працівників, які хворіють, налічується у металургійному виробництві $(11,3$ умовних осіб), а середня тривалість періодів між захворюваннями у металургійному виробництві та при відкритому видобуванні залізної руди перебуває майже на одному рівні $(61,0$ та 59,1 днів) (табл. 1).

За результатами власних досліджень встановлено, що ризик розвитку загальних захворювань $є$ вищим, ніж у контрольній групі для підземного видобування залізної руди $\left(\mathrm{R}_{1}=0,127\right)$, для відкритого видобування залізної руди $\left(\mathrm{R}_{1}=0,173\right)$, для металургійного виробництва $\left(\mathrm{R}_{1}=0,161\right)$, а співвідношення шансів захворіти на професійне захворювання (OR) становить 0,0516; 0,041 та 0,0061 відповідно.

Достовірність запропонованого підходу для оцінки професійного ризику при аналізі

Показники захворюваності з тимчасовою втратою працездатності у працівників

Таблиця 1 гірничо-металургійного виробництва $(p<0,05)$

\begin{tabular}{|c|c|c|c|}
\hline \multirow[b]{2}{*}{ Показник захворюваності } & \multicolumn{3}{|c|}{ Виробництво } \\
\hline & $\begin{array}{c}\text { Підземне } \\
\text { видобування } \\
\text { залізної руди }\end{array}$ & $\begin{array}{c}\text { Відкрите } \\
\text { видобування } \\
\text { залізної руди }\end{array}$ & $\begin{array}{l}\text { Металургійне } \\
\text { виробництво }\end{array}$ \\
\hline $\begin{array}{l}\text { Середня кількість осіб, що хворіють, у колективі, який } \\
\text { досліджується, n (умовних осіб) }\end{array}$ & 2,2 & 3,3 & 11,3 \\
\hline Середня тривалість періодів між захворюваннями (L), (дні) & 68,3 & 59,1 & 61,0 \\
\hline $\begin{array}{l}\text { Ймовірність захворіти здоровому працівнику } \\
\text { протягом доби }(\alpha)\end{array}$ & 0,0146 & 0,0170 & 0,0162 \\
\hline Ймовірність одужати хворому працівнику ( $\beta)$ & 0,1 & 0,081 & 0,084 \\
\hline Ризик ЗТВП $\left(\mathrm{R}_{1}\right)$ & 0,127 & 0,173 & 0,161 \\
\hline Відносний ризик (RR) & 0,10 & 0,13 & 0,09 \\
\hline Етіологічна частка професійного добору (EF) & $89,7 \%$ & $85,9 \%$ & $90,8 \%$ \\
\hline $\begin{array}{l}\text { Співвідношення шансів захворіти на професійне } \\
\text { захворювання (OR) }\end{array}$ & 0,0516 & 0,041 & 0,0061 \\
\hline Тривалість ЗТВП до переходу у ПЗ (дні) & 5,96 & 7,98 & 31,8 \\
\hline Клас умов праці за ДСНтаП № 248 & 3.2 & 3.2 & $2-3.1$ \\
\hline
\end{tabular}


захворюваності з тимчасовою втратою працездатності підтверджено під час проведення досліджень серед працівників основних професій підприємств підземного видобування залізної руди Кривого Рогу за 1992-2013 роки та встановлено, що працівники основних професій мають високий відносний ризик (RR) розвитку захворюваності 3 ТВП, який коливається від 9,5 до 52,1 (табл. 2).

Етіологічна частка професійних факторів у розвитку захворювань з ТВП становить 94,7$98,1 \%$, що вказує на високий ступінь зв'язку захворюваності з умовами праці та дуже високу професійну зумовленість ризику розвитку ЗТВП на виробництві.

\section{Висновки}

1. Запропонований підхід до оцінки професійного ризику при аналізі захворюваності з тимчасовою втратою працездатності у працівників гірничо-металургійного виробництва дозволяє проведення комплексного аналізу та оцінки стану здоров'я працівників 3 використанням їхніх показників ЗТВП та визначення причино-наслідкового зв'язку з умовами праці. Підвищення рівня ЗТВП у працівників промислових підприємств $€$ головним критерієм оцінки ступеня професійного ризику.

2. Проведення поглибленого аналізу захворюваності з тимчасовою втратою працездатності та встановлення причин, що призводять до її збільшення, дозволить проводити динамічний нагляд, моніторинг стану здоров'я кожного конкретного працівника задля своєчасного виявлення початкових проявів професійного захворювання та обов'язкового проведення відновлювального лікування 3 метою збереження працездатності працівника у своїй професії, розрахунок індивідуального безпечного терміну роботи та відкриють перспективи для подальших наукових досліджень, спрямованих на розроблення та впровадження ефективної системи керування професійним ризиком.

3. Впровадження зазначеної моделі інтегральної оцінки захворюваності з тимчасовою втратою працездатності в Україні дозволить знизити рівень професійної патології на 7-15\% та уникнути від 7 до 40 років трудових втрат для держави та підприємства.

ЛІТЕРАТУРА

1. Кундієв Ю.І., Нагорна А.М Професійне здоров'я в Україні. Епідеміологічний аналіз. К. : Авіценна, 2006. 316 с.

2. Нагорна А.М.,

Соколова М.П., Вітте П.М. та ін. Стан професійної захворюваності у період законодавчих змін в Україні. Український журнал з проблем медицини праці. 2016. № 1 (46). С. 3-17.

3. Концепція загальнодержавної цільової соціальної програми «Збереження і розвиток трудового потенціалу України на 2008-2017 роки». Український журнал з проблем медицини праці. 2007. № 4 (12). С. 3-9.

4. Левчук Н.М. Соціальний капітал та здоров'я населення в Україні. Демографія та соціальна економіка. 2011. № 1 (15) C. 47-57.

5. Нагорна А.М., Кононова І.Г., Гречківська Н.В. Сучасний стан та шляхи покращання організа-

Таблиця 2

Застосування методики аналізу захворюваності з тимчасовою втратою працездатності на прикладі працівників підземного видобування залізної руди м. Кривий Ріг за 1992-2013 роки

\begin{tabular}{|c|c|c|c|c|c|c|c|}
\hline \multirow[b]{2}{*}{ Показник ЗТВП } & \multicolumn{7}{|c|}{ Професія } \\
\hline & 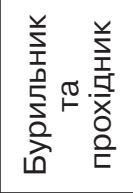 & $\begin{array}{l}5 \\
\frac{5}{0} \\
\frac{0}{0} \\
\frac{5}{0} \\
\frac{0}{0} \\
0\end{array}$ & 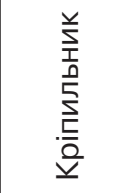 & 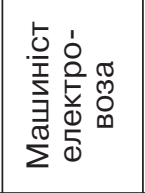 & 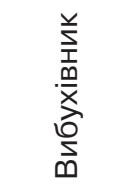 & 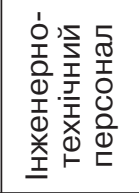 & 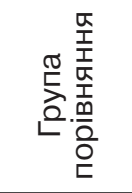 \\
\hline Рівень ЗТВП, k (1/рік) & 115,0 & 116,0 & 94,3 & 89,9 & 115,2 & 61,6 & 69,0 \\
\hline Дні непрацездатності, D & 997,8 & 991,1 & 878,4 & 896,8 & 1169,0 & 651,0 & 782,0 \\
\hline Кумулятивний коефіцієнт захворюваності, Cl & 0,0057 & 0,0322 & 0,0162 & 0,019 & 0,0886 & 0,0053 & 0,0017 \\
\hline Коефіцієнт захворюваності, IR & 0,00052 & 0,00292 & 0,00147 & 0,00172 & 0,00805 & 0,00048 & 0,00015 \\
\hline Відносний ризик, RR & 3,35 & $18,9^{\star}$ & $9,5^{\star}$ & $11,1^{\star}$ & $52,1^{\star}$ & 3,11 & 1,0 \\
\hline Етіологічна частка відносного ризику, EF,\% & 70,1 & 94,7 & 89,5 & 91,0 & 98,1 & 67,8 & 0,0 \\
\hline Середня кількість хворих, n & 2,7 & 2,7 & 2,4 & 2,45 & 3,2 & 1,78 & 4,3 \\
\hline Поширеність, PR & 0,0135 & 0,075 & 0,041 & 0,052 & 0,24 & 0,015 & 0,011 \\
\hline Середня тривалість захворювання, I (днів) & 8,7 & 8,5 & 9,3 & 10,0 & 10,1 & 10,6 & 10,5 \\
\hline $\begin{array}{l}\text { Середня тривалість періодів між } \\
\text { захворюваннями, L (днів) }\end{array}$ & 634,8 & 113,2 & 224,5 & 190,8 & 41,2 & 681,4 & 987,9 \\
\hline Ймовірність захворіти (здоровим особам), $\alpha$ & 0,0016 & 0,0088 & 0,0044 & 0,0052 & 0,0243 & 0,0015 & 0,00101 \\
\hline Ймовірність одужати (хворим особам), $\delta$ & 0,115 & 0,117 & 0,107 & 0,1 & 0,099 & 0,094 & 0,095 \\
\hline Кількість випадків ЗТВП х100, K & 115 & 116 & 94,3 & 89,9 & 115,2 & 61,6 & 69 \\
\hline Кількість випадків ПЗ ×100, p & 4,3 & 2,9 & 1,76 & 0,94 & 7,8 & 0,33 & 0,5 \\
\hline Співвідношення шансів захворіти на ПЗ, OR & 0.037 & 0,025 & 0,018 & 0,01 & 0,068 & 0,0053 & 0,0072 \\
\hline $\begin{array}{l}\text { Швидкість переходу членів досліджуваної групи } \\
\text { від стану «здоровий» до стану «хворий», n }\end{array}$ & 2,14 & 1,25 & 1,57 & 1,45 & 1,85 & 2,24 & 2,09 \\
\hline Тривалість ЗТВП до переходу у ПЗ L (дні) & 9,5 & 12,8 & 16,5 & 23,2 & 3,0 & 31,3 & 28,0 \\
\hline Статистичний показник, I & 0,108 & 0,111 & 0,102 & 0,095 & 0,094 & 0,091 & 0,09 \\
\hline
\end{tabular}

Примітка: ${ }^{*}$ різниця достовірна $(p \leq 0,05)$. 
MODERN MODEL OF INTEGRAL RISK EVALUATION OF DISEASES WITH TEMPORARY DISABILITY

IN THE WORKERS OF MODERN MINING AND SMELTING INDUSTRY OF UKRAINE

Oriekhova O.V., Pavlenko O.I.

SE «Ukrainian Research Institute for Industrial Medicine», Kryvyi Rih, Ukraine

Objective: We harmonized the method for the analysis and evaluation of the morbidity associated with the conditions of work, with international standards. Materials and methods: We used hygienic, epidemiological, mathematical and statistical methods in the study.

The main group was represented by 19033 workers of 8 leading mining and smelting enterprises.

Control group included 6270 persons who were not exposed to harmful production factors during the course of their work. The study of the incidence of temporary disability was conducted on the basis of the analytical treatment of the disability letters and the report on the causes of temporary disability (form TN-23) for 5 years (2010-2014).

Results: We proposed an approach to the estimation of the risk of morbidity with a temporary disability, which, unlike the current one, allows not only to assess the level of the morbidity but also to identify the causes of its change and give a quantitative assessment of the factors affecting it: industrial harmful factors, medical care, quality of professional selection, etc. The quantitative correlation between these factors is a solid ground for the development of preventive measures which allow reducing the level of professional pathology by $7-15 \%$ and preserve from 7 to 40 years of labour losses for the state and enterprises. According to the results of our research, the risk of the development of general diseases is higher in the main group in the workers of the underground mining of iron ore $(R R=0.127)$, open mining of iron ore ( $R R=0.173)$, and metallurgical production $(R R=0.161)$ than in the control group, and the ratio of the chances to have an occupational disease $(O R)$ is $0.0516,0.041$, and 0.0061 , respectively. The workers of main professions have a high relative risk $(R R)$ of development the incidence of TBV which varies from 9.5 to 52.1 .

The etiological part of the professional factors in the development of diseases with TBP is 94.7-

$98.1 \%$, which indicates a high degree of connection of the morbidity with the conditions of work and a very high professional risk factor for the development of the risk of morbidity with a temporary disability at the workplace.

Conclusions: Obtained parameters of morbidity, calculated on the basis of the analysis of the incidence of temporary disability, are necessary for the assessment of the risk of the development of professional and professionally determined pathology, while integral parameters, taking into account the incidence of diseases and the severity of the consequences, are crucial.

\section{Keywords: occupational risk, incidence with temporary disability, integral assessment, mining and smelting industry.}

ції та контролю над медичними оглядами працівників у шкідливих і небезпечних умовах. Український журнал з проблем медицини праці. 2014. № 3 (40). С. 10-18

6. Кононова І.Г. Медичні огляди працівників у шкідливих та небезпечних умовах праці: проблеми та шляхи їх вирішення. Актуальні проблеми діагностики, лікування та профілактики професійних захворювань в Україні : матер. науково-практ. конф. з міжнародною участю. Кривий Ріг, 2013.

C. 34-40.

7. Niu Sh. ILO technical and ethical guidelines for workers' health surveillance. Journal of UOEH. 2000. Vol. 22, Suppl.

P. 8-18.

8. Constitution of the World Health Organization. Basic Documents. Forty-fifth edition, Supplement, October 2006.

9. CSDH. Closing the gap in a generation: health equity through action on the social determinants of health. Final Report of the Commission on Social Determinants of Health. Geneva : WHO, 2008. 129 p. URL : www.who.int/social determinants/final report/en/

10. Догле Н.В., Юркевич А.Я. Заболеваемость с временной утратой трудоспособности. М. Медицина, 1984. 176 с.

\section{REFERENCES}

1. Kundrev Y.U. and Nahorna A.M. Professional Health in Ukraine. Epidemiological Analysis. Kyiv : Avitsenna; 2006 : 316 p. (in Ukrainian)

2. Nahorna A.M., Sokolova M.P., Vitte P.M., Kononova I.H. and Piatnytsia-Horpynchenko N.K. Ukrainian Journal of Occupational Health. 2016; 1 (46) : 3-17 (in Ukrainian). 3. Kontsept zahalnoderzhavnoi tsilovoi sotsialnoi prohramy «Zberezhennia i rozvytok trudovoho potentsialu Ukrainy na 2008-2017 roky» [Concept of the National Target Social Program «Preservation and Development of Labor Potential of Ukraine for 2008-2017»]. Ukrainian Journal of Occupational Health. 2007; 4 (12) : 3-9 (in Ukrainian).

4. Levchuk N.M. Demohrafiia ta sotsialna ekonomika. 2011; 1 (15) : 47-57 (in Ukrainian).

5. Nahorna A.M.

Kononova I.H. and Hrechkivska N.V. Ukrainian Journal of Occupational Health. 2014; 3 (40) : 10-18 (in Ukrainian).

6. Kononova I.H. Medychni ohliady pratsiuiuchykh v shkidlyvykh ta nebezpechnykh umovakh pratsi: problem ta shli- akhy yikh vyrishennia [Medical Examinations of the Persons Working under Harmful and Dangerous Conditions of Work Problems and Ways for their Solution]. In : Aktualni problemy diahnostyky, likuvannia ta profilaktyky profesiinykh zakhvoriuvan v Ukraini: mater. konf. [Actual Problems of Diagnosis, Treatment and Prevention of Occupational Diseases in Ukraine : mater. conf.]. Kryvyi Rih. 2013; 34-40 (in Ukrainian).

7. Niu Sh. J. UOEH. 2000; $22: 8-18$

8. Constitution of the World Health Organization. Basic Documents. Forty-fifth edition. Supplement. Geneva : WHO, 2006.

9. CSDH. Closing the Gap in a Generation: Health Equity through Action on the Social Determinants of Health. Final Report of the Commission on Social Determinants of Health. Geneva : WHO, 2008. 129 p. URL : www.who.int/social determinants/final report/en/

10. Dogle N.V. and

Yurkevich A.Ya. Zabolevaemost s vremennoy utratoy trudosposobnosti [Morbidity with Temporary Disability]. Moscow : Meditsina ; 1984 : 176 p. (in Russian).

Надійшла до редакції 17.04.2019

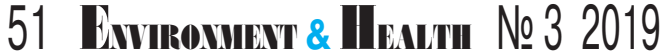

